\title{
Facility Registration and Initial Regulatory Compliance Activities for Acidified Food and Low-Acid Canned Food Processors in Florida ${ }^{1}$
}

\author{
Matthew Krug and Soohyoun Ahn²
}

This factsheet is one in a "Food Entrepreneurship in Florida" series, which assists beginning and established food entrepreneurs by providing them information on topics highly relevant to starting and running a food business-regulations, safety, labeling, processing, and marketing. This series serves as a useful guide to help run successful food-related business.

\section{Background}

Food businesses are subject to a wide range of regulatory requirements. Understanding and implementing the necessary steps to comply with each regulation takes dedication, time, and money. Food entrepreneurs who desire to produce and sell acidified foods or low-acid foods packaged in hermetically sealed containers (low-acid canned foods) must abide by specific Food and Drug Administration (FDA) regulations. This document intends to clarify the initial steps food entrepreneurs must implement to comply with these regulations.

\section{Acidified and Low-Acid Food}

Acidified and low-acid canned food can pose a risk to human health if critical factors are not controlled during processing. The spore-forming bacterium Clostridium botulinum (C. botulinum) is especially hazardous in these food products because it grows in anaerobic environments and produces a nerve toxin that causes serious paralytic illness or death. C. botulinum spores will not germinate and grow in foods with a $\mathrm{pH}$ of 4.6 or below; therefore, control of food acidity is an important component addressed in the acidified food regulation. The $\mathrm{pH}$ of low-acid canned foods is above this 4.6 threshold, so these products must undergo intense heat processing to control biological hazards, especially C. botulinum spores. Relevant terms, including acidified and low-acid foods as defined in the Code of Federal Regulations (Title 21, parts 113 and 114), are listed below.

\begin{tabular}{|c|l|}
\hline \multicolumn{1}{|c|}{ Acid Foods } & $\begin{array}{l}\text { Foods that have a natural } \mathrm{pH} \text { of } \\
\text { 4.6 or below }\end{array}$ \\
\hline Acidified Foods & $\begin{array}{l}\text { Low-acid foods with a water } \\
\text { activity greater than } 0.85 \text { to } \\
\text { which acid(s) or acid food(s) } \\
\text { are added, resulting in a } \\
\text { finished equilibrium pH of } 4.6 \\
\text { or below }\end{array}$ \\
\hline Low-Acid Foods & $\begin{array}{l}\text { Any foods, other than alcoholic } \\
\text { beverages, with a finished } \\
\text { equilibrium pH greater than } \\
4.6 \text { and a water activity greater } \\
\text { than 0.85* }\end{array}$ \\
\hline Water Activity $\left(\mathrm{a}_{\mathrm{w}}\right)$ & $\begin{array}{l}\text { A measure of the free moisture } \\
\text { in a product }\end{array}$ \\
\hline
\end{tabular}

*Exception to this definition is tomatoes and tomato products that have a finished equilibrium $\mathrm{pH}$ of 4.7.

1. This document is FSHN19-2, one of a series of the Food Science and Human Nutrition Department, UF/IFAS Extension. Original publication date February 2019. Visit the EDIS website at https://edis.ifas.ufl.edu for the currently supported version of this publication.

2. Matthew Krug, state specialized agent II, Food Science and Human Nutrition Department, UF/IFAS Southwest Florida Research and Education Center, Immokalee, FL 34142; and Soohyoun Ahn, assistant professor, Food Science and Human Nutrition Department; UF/IFAS Extension, Gainesville, FL 32611.

The Institute of Food and Agricultural Sciences (IFAS) is an Equal Opportunity Institution authorized to provide research, educational information and other services

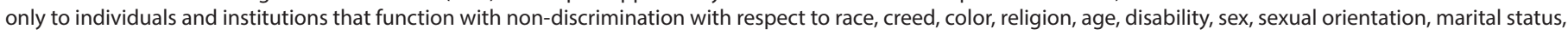
national origin, political opinions or affiliations. For more information on obtaining other UF/IFAS Extension publications, contact your county's UF/IFAS Extension office. U.S. Department of Agriculture, UF/IFAS Extension Service, University of Florida, IFAS, Florida A \& M University Cooperative Extension Program, and Boards of County Commissioners Cooperating. Nick T. Place, dean for UF/IFAS Extension. 


\section{Facility Registration and Compliance Activities}

Commercial processors (referred to as "you" for the remainder of this document) of acidified or low-acid canned foods must complete an array of activities before production begins. You must properly register your facility and food product with the FDA and comply with requirements found in the acidified food (21 CFR 114) or low-acid canned food (21 CFR 113) regulations. You must also implement other current good manufacturing practices (CGMP or simply GMPs) found in 21 CFR part 117. The initial steps of this process are listed below.

\section{Training}

You must complete the Better Process Control School (BPCS) curriculum and successfully pass chapter exams to receive a certificate. To register, use the links below.

In-person: https://www.gmaonline.org/resources/scienceeducation-foundation/better-process-control-schools/ sef-bpcs-partner-schools-listing-program/

Online: http://foodscience.tennessee.edu/ betterprocesscontrolschool/

\section{Facility Registration}

You must register your food production establishment under the FDA Food Facility Registration (FFR) system using FDA Form 3537. You can identify your facility as an Acidified/Low-Acid Food Processor and you will receive an FFR number and PIN to be used in further registration activities. Instructions for online facility registration are found here: https://www.fda.gov/Food/GuidanceRegulation/FoodFacilityRegistration/ucm073706.htm.

You must register your facility by submitting FDA Form 2541 online using the following instructions: https:// www.fda.gov/downloads/Food/GuidanceRegulation/ UCM309486.pdf.

\section{Establish Scheduled Process}

You must find a process authority - an individual or group expert in the development, implementation, and evaluation of thermal and/or aseptic processes for shelf-stable foodsto evaluate your food product and develop a scheduled process. A list of processing authorities in the United States can be found here: www.afdo.org/foodprocessing.
Scheduled processes will identify values for critical parameters, such as temperature, time, $\mathrm{pH}$, and container size, that must be followed during regular production. After evaluation, the process authority will issue an official letter stating these values and other process information.

\section{Process Filing}

Once you have a scheduled process for your product, you must file this process by filling out an appropriate FDA form. These forms may be submitted on paper or electronically.

- FDA 2541d-Low-Acid Retorted Method

- FDA 2541e-Acidified Method

- FDA 2541f-Water Activity/Formulation Control Method

- FDA 2541g-Low-Acid Aseptic Systems

FDA guidance on process filing is found here: https://www. fda.gov/Food/GuidanceRegulation/GuidanceDocumentsRegulatoryInformation/ucm309376.htm.

\section{Facility and Equipment}

Each operating facility must be designed and maintained in a condition that protects against the contamination of food. You must ensure that the facility and equipment are designed in a way that allows for adequate implementation of your scheduled process and meets any CGMP criteria. More information on CGMPs is found in the "Other Resources" section.

\section{Inspection}

Prior to commercial processing, your facility and process must undergo an official inspection. In Florida, this inspection is conducted by the Florida Department of Agriculture and Consumer Services (FDACS).

You can apply for an FDACS inspection here: https:// www.freshfromflorida.com/Business-Services/FoodEstablishment-Inspections/Food-Establishment-Permit/ Food-Establishment-Inspection-Application.

\section{Other Compliance Activities}

After initial facility and process inspection is complete, you must continue to address, implement, and monitor CGMP's found in 21 CFR parts 113,114 , or 117. These activities may include the following: 
- Personnel

- Plant and grounds

- Sanitary facilities and controls

- Equipment and utensils

- Product preparation

- Processes and controls

- Containers

- Process deviations

- Warehousing and distribution

- Record keeping

- Defect action levels

\section{Other Resources}

FDA. "Code of Federal Regulations Title 21, Part

108, Emergency Permit Control” (https://www.ac-

cessdata.fda.gov/scripts/cdrh/cfdocs/cfcfr/CFRSearch.

cfm?CFRPart=108).

FDA. "Code of Federal Regulations Title 21, Part 110,

Current Good Manufacturing Practice in Manufacturing, Packing, or Holding Human Food" (https://www. accessdata.fda.gov/scripts/cdrh/cfdocs/cfcfr/CFRSearch. cfm?CFRPart=110).

FDA. "Code of Federal Regulations Title 21, Part 113, Thermally Processed Low-Acid Foods Packaged in Hermetically Sealed Containers" (https://www.accessdata.fda.gov/scripts/ cdrh/cfdocs/cfcfr/CFRSearch.cfm?CFRPart=113).

FDA. "Code of Federal Regulations Title 21, Part 114, Acidified Foods" (https://www.accessdata.fda.gov/scripts/ cdrh/cfdocs/cfcfr/CFRSearch.cfm?CFRPart=114).

FDA. "Code of Federal Regulations Title 21, Part 117, Current Good Manufacturing Practice, Hazard Analysis, and Risk-Based Preventive Controls for Human Food" (https://www.accessdata.fda.gov/scripts/cdrh/cfdocs/ cfCFR/CFRSearch.cfm?CFRPart=117).

FDA. "Low-Acid Foods Packaged in Hermetically Sealed Containers (LACF) Regulation and the FDA Food Safety Modernization Act: Guidance for Industry" (https://www. fda.gov/downloads/Food/GuidanceRegulation/GuidanceDocumentsRegulatoryInformation/UCM569792.pdf). 